\title{
Food justice and Christian ethics
}

\author{
Author: \\ Heinrich Bedford-Strohm ${ }^{1,2,3,4}$ \\ Affiliations: \\ ${ }^{1}$ Extraordinary professor, \\ Department of Ecclesiology \\ and Ethics, University of \\ Stellenbosch, South Africa \\ ${ }^{2}$ Honorary professor, \\ Systematic Theology, \\ University of Bamberg, \\ Germany \\ ${ }^{3}$ Presiding Bishop of the \\ Lutheran Church of Bavaria, \\ Germany \\ ${ }^{4}$ Research associate, \\ Department of Dogmatics \\ and Christian Ethics, \\ University of Pretoria, \\ South Africa \\ Correspondence to: \\ Heinrich Bedford-Strohm

\section{Email:} \\ Heinrich.Bedford-Strohm@ \\ elkb.de \\ Postal address: \\ Katharina-von-Bora-Straße \\ 11-13, 80333 München

\section{Dates:} \\ Received: 25 July 2012 \\ Accepted: 08 Oct. 2012 \\ Published: 06 Dec. 2012 \\ How to cite this article: \\ Bedford-Strohm, H., 2012, \\ 'Food justice and Christian \\ ethics', Verbum et Ecclesia \\ 33(2), Art. \#768, 6 pages. \\ http://dx.doi.org/10.4102/ \\ ve.v33i2.768
}

C 2012. The Authors. Licensee: AOSIS OpenJournals. This work is licensed under the Creative Commons Attribution License.
The article dealt with the moral and political problem of international food justice in which the deep contradiction between the present situation of malnourishment and starvation in large parts of the global population on the one hand and the biblical notion of the preferential option for the poor on the other hand was described. This ecumenically widely accepted notion was clarified in several aspects. How deeply this is rooted in the history of Christian social thought was shown by Martin Luther's writings on the economy which have remained relatively unknown in the churches and in the scholarly world. The article then presented three models of Christian economic ethic: the technical economic model, the utopian economic model and the public theological economic model. On the basis of the public theological model seven challenges for international food justice were presented. The basis for these challenges is an understanding of globalisation which guarantees just participation for everyone and deals with nature in an ecologically sustainable way. The interests of small farmers are the basis for judging the activities of big agro-corporations. Public theology is the background for an active involvement of the churches as agents of a global civil society to promote international food justice.

\section{Introduction}

After the end of the Third Reich in Germany many people asked: how could we see Jewish people being deported and not act?

What will the question we shall ask in 50 years about our own time today be? Even though global food injustice cannot be compared to the mass murder of the Nazis, because it does not rely on a systematic intentional effort to destroy human beings, the moral scandal is obvious. The victims of our present global economic structures - as unintended as they may be - can leave nobody, who has any moral sensitivity, untouched.

This is all the more the case if we speak as Christians. As Christians we speak of a God who is presented in the Bible, inseparably linked with a preferential option for the poor. This is such a prominent trait of all biblical traditions that we can follow it from the beginning of the development of the faith of Israel up to the New Testament and its characterisation of Jesus. The God of Israel who reveals his very being in the burning bush, defines himself as the one who will lead his people from oppression into freedom. The law given to Israel by God therefore especially protects the weak: care for the slaves, because you have been a slave yourself and I have led you into freedom! The prophets passionately struggle for justice, they criticise a religious cult without justice:

I hate, I despise your festivals, and I take no delight in your solemn assemblies. Even though you offer me your burnt offerings and grain offerings, I will not accept them; and the offerings of well-being of your fatted animals I will not look upon ... Take away from me the noise of your songs; I will not listen to the melody of your harps. But let justice roll down like waters, and righteousness like an ever-flowing stream. (Am 5:21-24)

And then Jesus is presented as the one who came to preach the gospel to the poor and who can even be identified in those who are hungry, thirsty, naked, sick, in prison and strangers: 'Truly I tell you, just as you did it to one of the least of my brothers and sisters, you did it to me' (Mt 25:40).

I do not need to further develop the biblical basis of the option for the poor. It speaks to us in a very specific situation. The Millenium Development Goals to halve, between 1990 and 2015, the proportion of people who suffer from hunger is far from being reached. The Millenium Development Goals Report (United Nations 2010:11) even indicates that hunger may have spiked in 2009 as a consequence of the global economic crisis currently affecting about one billion people. The overall numbers would be even more catastrophic if China had not been so successful in decreasing hunger in their huge country. The reasons for this severe global situation are manifold: 
the economic crisis has caused a loss of jobs in many countries of the South. For example, one million people lost their jobs in South Africa in the year after the crisis, therefore losing their source of income. At the same time certain segments of the emerging markets, like South Africa, became increasingly rich. Increasing demand for food from emerging markets based on such additional buying power, increased prices with adverse consequences for the poor. Price increases were also due to speculation, which shifted from the financial markets to the food market. Supply was limited due to a change in the use of the land by growing agrofuel plants rather than food, but also to weather volatilities caused by the global warming. And, of course, the conditions of trade on the world markets continued to be shaped by the interest of the powerful countries of the North rather than by those countries that would most need better conditions to combat hunger in their own countries.

I shall leave it to others to go deeper into these aspects of the global food situation and the political and economic dynamics connected with it. I would rather like to lay the theological groundwork to deal with these problems in three steps.

Firstly, I want to sharpen the profile of the option for the poor by describing four important characteristics. I shall support the importance of this option by referring to Martin Luther. Then I would like to introduce several models of economics that relate differently to a theological approach based on the option for the poor. Finally, I want to outline seven challenges to the struggle for international food justice and share some thoughts about the role the churches can play in it.

\section{Theological clarification - the option for the poor}

I would like to sharpen the profile of the option for the poor as a fundamental principle of a Christian understanding of justice by presenting four features that define its content and function (Bedford-Strohm 1993).

The first and most fundamental clarification deals with the question of what poverty is in the first place. Material poverty is only one of the conditions that are meant when we talk about the option for the poor. There is also a form of poverty that has been called socio-cultural poverty (Boff \& Pixley 1987:25). It includes various forms of discrimination, such as discrimination based on race, gender or sexual orientation. It is important to say that the concept of socio-cultural poverty should not be used to mystify the brutality of the daily fight for survival which means material poverty. Material poverty - and this refers to especially a lack of food - remains the most central form of poverty, and it is usually one dimension of socio-cultural poverty. The core of what poverty means is understood best, if we define it as lack of participation. There is always a lack of participation when people are excluded from the economic and social processes of society nationally and internationally. Material poverty and especially lack of food must be seen as a lack of participation in multiple ways because it usually means the exclusion from the economic and social processes. The fact that political offices are almost never held by people who have suffered poverty is only one indication for this fact. The importance of participation is also the focus of my second clarification.

My second clarification affirms the universal horizon of the option for the poor. This option has often been criticised as exclusive and divisive. And it is certainly true: the fact that it is a preferential option means that it is a conflictual option, that it supports certain interests as opposed to other interests. But ultimately it is not a partial but a universal option. It intends justice for all. It is only partial as long as this universal intention is blocked by the pursuit of the illegitimate interests of some at the cost of others. Preference for the poor does not aim at excluding the rich but it intends to include those who are now excluded from the benefits of society. This preference is a necessary step on the way to the inclusion of everyone in the benefits of mutual cooperation. Let me illustrate the correlation between the universal and the preferential sense of the option for the poor with the so called golden rule which is presented in the New Testament as a summary of biblical ethics: 'Do unto others as you would have them do unto you' (Mt 7:12). The golden rule is a universal option based on reciprocity. If we apply it to our question of justice, we can hardly avoid the conclusion that it leads directly to the option for the poor: be in solidarity with the struggle of the poor for a decent life just as you want to live a decent life, as well. The preferential option is only a logical consequence of the universal option, applied to a particular political situation.

My third clarification leads my interpretation of the golden rule one step further, beyond the doorsteps of theology. The option for the poor is not only strongly rooted in biblically based theological ethics, but it is also a central feature of a philosophical approach to justice. As some of you will anticipate, I am referring to John Rawls' famous theory of justice. I not only believe that its central features were able to hold out in the face of criticism from various sides, but I also think that they are highly compatible with Christian ethics. The difference principle, which is one of the two main principles that Rawls argues for philosophically, is quite close to the option for the poor: differences in wealth, income, and power, are only legitimate if they are '(a) to the greatest benefit of the least advantaged and (b) attached to offices and positions open to all under conditions of fair equality of opportunity' (Rawls 1971:83). The connection between the preference for the least advantaged and the openness of societal positions to all, is a close philosophical analogy to the participatory understanding of the option for the poor as I have interpreted it. It is also noteworthy that Rawls explicitly argues 'that the difference principle expresses a conception of reciprocity' (Rawls 1971:102). The golden rule has a bridging function between biblically based theological ethics on one side and philosophical ethics on the other side. Both lead from a universal ethic of reciprocity to the option for the poor as the central criterion for justice. 
This role as criterion for justice has to be understood in a very specific way - and this is my fourth and final clarification. The option for the poor is a critical standard for reviewing the present situation in the national or international context. Any use of this criterion simply to legitimise an independently won bias for a certain economic order whatever it may be, is against its biblical intentions. Biblically based Christian ethics is always critical ethics. Jesus' proclamation of the kingdom of God was the eschatological call to a new life. It was the call to be the salt of the earth and light of the world. It was the call to not look at the speck in our neighbour's eye but at the log in our own eye.

The option for the poor calls us in the powerful countries of the Western world to not point toward others and their responsibilities but first of all to look at ourselves and our own ways to contribute to worldwide injustice. This option is to be used as a critical criterion for our deliberations on the appropriate economic strategies towards more justice.

I want to summarise the outcome of my four clarifications:

- Firstly: the situation which the option for the poor addresses, is a lack of participation.

- Secondly: the exclusive preference of the poor is a logical consequence of its inclusive universality.

- Thirdly: it is as plausible on a philosophical basis as it is on a biblical basis.

- Fourthly: it is only appropriately understood as a core part of Christian ethics, if it is used as a critical criterion.

I believe that these four clarifications that I have proposed are needed to give the option for the poor a profile that prevents it from just being a verbal slogan without any orientation value.

Before I turn to economics, let me take a few minutes to look at the father of Lutheranism, Martin Luther himself. Not many people think of the option for the poor when they hear his name. That is a mistake as I shall try to show.

\section{Martin Luther's passion for justice}

Luther's numerous works on economic ethics constitute the less well-known part of his work. This is all the more surprising since his passionate intervention for social justice and the poor has lost none of its topicality. In these works, Luther can really be recognised as a 'public theologian'. Even though he did not have the theoretical or political intellectual scope of today at his disposal, he involved himself - often with biting criticism - in public affairs. In his works on economic ethics he talks about the Christian-ethical priority given to the weak in the social upheavals of nascent early capitalism.

The contemporary background to his remarks cannot be directly transferred to the economic and social situation of today. But despite the limitations of Luther's traditionorientated mentality, his basic ethical intentions - strongly influenced by the Bible - are highly relevant to the economy of today, with a distribution of wealth throughout the world probably even more disproportionate than in the completely different world economy of his day. It is not going too far to say that the key characteristic of Luther's basic orientation in economic ethics is the 'priority of the poor'. An example is Luther's severe criticism of the way in which the price of goods is linked to the law of supply and demand:

Among themselves the merchants have a common rule which is their chief maxim and the basis of all their sharp practices, where they say: 'I may sell my goods as dear as I can.' They think this is their right. Thus occasion is given for avarice, and every window and door to hell is opened. What does it mean but this: I care nothing about my neighbour; so long as I have my profit and satisfy my greed, of what concern is it to me if it injures my neighbour in ten ways at once? There you see how shamelessly this maxim flies squarely in the face not only of Christian love but also of natural law. (Luther 1962:247)

Luther fights against the orientation of prices to the market, because this takes no account of the needs of the weak. His alternative is orientation to a just price:

The rule ought to be, not, 'I may sell my wares as dear as I can or will', but, 'I may sell my wares as dear as I ought, or as is right and fair'. (Luther 1962:248)

He then goes on to describe ten practices of the multinational corporations of his time which took advantage of the needs of the poor in pursuit of their own greed, such as raising prices by forming monopolies (Luther 1962:261-269).

Also striking is Luther's insistence that politicians should play an active role to curb unrestricted economic power:

... the best and safest way would be to have the temporal authorities appoint in this matter wise and honest men to compute their costs of all sorts of wares and accordingly set prices which would enable the merchant to get along and provide for him an adequate living. (Luther 1962:249)

This passage leaves no doubt, that - for Luther - government has a place in giving the necessary frame for economic activity, even though we cannot advocate his solution of governmental price control today.

Luther attacks politicians for being too close to business. His scepticism regarding the independence of politicians and his call for the primacy of politics speaks to us today in many ways. As regards the economic practice of the multinational companies, such as the Fuggers, which at that time were becoming increasingly powerful, Luther says:

Kings and princes ought to look into this matter and forbid them by strict laws. But I hear that they have a finger in it themselves, and the saying of Isaiah [1:23] is fulfilled, 'Your princes have become companions of thieves.' They hang thieves who have stolen a gulden or half a gulden, but do business with those who rob the whole world and steal more than all the rest, so that the proverb remains true, 'Big thieves hang little thieves.' As the Roman senator Cato said, 'Simple thieves lie in dungeons and sticks; public thieves walk abroad in gold and silk. (Luther 1962:271-272)

These words express a protest against the alliance of power and money, denying the interests and rights of the poor.

Luther's criticism of early capitalism, for which radical passion many more examples could be given, cannot simply be transferred to our time. Behind it is a conservative adherence to an old feudal system that certainly cannot be the solution for us today. But the background to Luther's 
moral outrage has lost nothing of its topicality. It is the 'freedom of a Christian', on which the Reformation focussed, that sympathises with the fate of the neighbour, particularly the neighbour blighted by poverty, and looks for ways to improve his situation. As Klaus Nürnberger has concluded in his great study of Luther's work from a perspective of the South African context:

Luther emphasized the public responsibility of the church. Church leaders must go public with a clear message; congregations must become caring communities and individual members must act as Christians in their secular contexts. (Nürnberger 2005:298)

Therefore it is quite safe to assume that Luther, had he lived in our time with its global horizon, would be a passionate advocate of international food justice. We have found clear indication that the option for the poor which we have recognised as a characteristic trait of the Bible's understanding of God, turns out to be a central aspect of Martin Luther's theology as well. It is a strange phenomenon that Lutheran churches and theology in the North have widely honoured and reflected on Luther's doctrine of justification but almost ignored his fervent option for the poor.

But how can we connect the option for the poor with actual economic policies? This is a key question if we try to find ways towards international food justice. There is considerable disagreement about the place and importance of ethical reasoning in questions of food justice. This has to do with the way economics is understood.

I see three different models of understanding economics which connect economic and ethical reasoning in very different ways.

\section{Three models of Christian economic ethics}

The technical economic model can be treated very briefly as follows. It has to be seriously questioned from a theological point of view. In its strong version it denies all considerations which go beyond questions of purely instrumental reason, as for example, the best strategy for the maximisation of the global food output. In its milder version it implies that beyond a basic human understanding of values, like fighting human misery, there is no need for ethical reflection. Since almost all people can agree on those basic human values, there is no need for ethical intervention in the field of economics. The challenge rather lies in how to find the right economic strategies to implement ethical goals which all people more or less agree upon.

Those who come from this model are usually sceptical or even hostile to religion-based interventions in the debate on economics. Especially in its weaker form this model can be valuable and should not simply be dismissed. If theologically based economic ethics underestimate the difficulty of finding strategies which actually work, interventions from the standpoint of this model can have a healthy sobering effect. It has to be said equally clearly though that this model, especially in its stronger form, tends to be ideological, because it lacks consciousness of its own presupposed goals and values.
The goals and values can be seen as the driving motive of a second model which I call the utopian economic model. The utopian model fundamentally criticises the existing social and economic order with all its acceptance of greed and egoism and tries to describe alternatives to this order which are based on the equal sharing of resources. Capitalism is categorically condemned because it works on the basis of seeking profits, an attitude which is seen in fundamental contradiction to the Christian commandment to love and serve the other (see e.g. Duchrow 1995). The failure of capitalism is proved by the fact that it cannot make sure that every human person has enough food to live. In its strongest version it even demonises capitalism as the source of all evil. In its milder version it focuses on the alternatives.

The description of this model of an economy, driven by mutual respect and solidarity between human beings and by an awareness of the dignity of nature (which is nonhuman) can have a strong inspirational effect and can generate creative imagination for new economic thinking - beyond the horizons of traditional concepts which are sometimes much narrower than we realised when we were brought up with them. And there is an obvious closeness between this model and biblical visions equally describing the new values and new relationships of Shalom in the kingdom of God (see Segbers 2002).

The weakness of this model is its primary reliance on inspiration. Fundamental alternatives in organising economics along the lines of the sharing of resources work if people strongly identify with their goals and values. If conflicts of interest and struggle for scarce resources are not in the way, alternative models can work and inspire others. They can however not be the primary basis for the public voice of the church in economic matters, as long as not all people are converted and accept those new values, lying on our doorstep. Basing the economy on the general readiness to freely share resources is thus problematic. If utopian alternatives applied in politics lead to consequences opposite to their intentions, for example, a sharp decline in generating wealth, they can even be ethically deeply questionable.

The strength of the utopian economic model is its inspirational message that another world is possible. The danger of it is a lack of guidance in a situation in which the economy still has to be organised in a way that takes into account existing selfinterest and the conflicts in the distribution of goods involved in it. If people do not spontaneously share, there need to be rules and incentives which both encourage the production of wealth and its fair distribution. The utopian economic model leaves those alone who, for example politicians, have the power to actually shape those rules.

That is why we need a third model which I call the public theological economic model. The public theology model cherishes the inspirational potential of the utopian model. But it goes beyond this model by explicitly reflecting on the concrete effects of certain possible mechanisms, including possible unintended counterproductive effects of mechanisms, which at first sight seem especially ethically, valuable. The public theological model has a natural 
closeness to an ethic of responsibility because it sees the reflection of the consequences of its considered alternatives for action, as an integral part of its ethical argument. Only when theologically-based ethical goals are mutually related to a careful reflection of political and economic strategies and their expected consequences, can theological ethics really give guidance to politics and economics and the debate about it in civil society (see Bedford-Strohm 2007).

This model however, also helps economists to critically reflect on their own thinking. What are the implicit goals and values of economic strategies and how are the priorities set? And how do we measure the success of economic efforts? Measuring such success by simply using the global food production statistics implies that different goals for developing the instruments to measure the improvement of the situation of the poor and assessing the progress in ecological transformation were used. Good economic theory includes such accounts for its goals and purposes in its reflections.

What are the consequences of this reflection on theology and economics for our question of international food justice? I want to point towards five aspects.

\section{Seven challenges for international food justice}

Firstly, it is clear after what we have said about the participatory dimension of the option for the poor, that international food justice does not only mean the delivery of enough food to every human being. It means more. It means the empowerment to be an agent in providing food for oneself. It means just participation in social and economic processes which generate a living for everybody. Therefore, even if those are right who say that the present form of capitalism, in which powerful companies use the newest technology, is best able to generate the highest possible food production which then only would have to be distributed fairly worldwide, this cannot be seen as an approach in tune with the option for the poor. The poor remain dependant rather than that they are participating actively in food production. If food production more and more relies on Genetic Modified Organisms (GMO), farmers become increasingly dependant on the seeds of Monsanto and others. Furthermore, if the land is owned by powerful companies which direct their decisions toward the goal of the highest possible profit, there is no basis for a just participation of all. Effective farming must therefore go hand in hand with a wide distribution of farming land property.

Secondly, proposals which see globalisation as the main or only source of the problem which focuses on small local farmer subsistence, need to carefully analyse the consequences of this approach. Will this approach sufficiently protect against the ups and downs of local weather-related harvest output? Is it really in the interest of the poor to reject the use of comparative cost advantages by the global trade? If farm cooperatives in South Africa can make great wine and sell it in Europe, can this not be a way to increase the participation of the poor in these ventures?
Therefore, thirdly, there is good reason to not reject globalisation but to reorient globalisation in a way that limits the power of transnational agents who control the markets and that would protect and empower those agents who are small and therefore lack market power.

Fourthly, generating food justice is not about a 'yes' or a 'no' to market liberalisation. Market liberalisation is ethically desirable if it increases the possibilities for those small agents to develop their own economic potential. Liberalisation is ethically questionable if it is only an ideological symbol for protecting the interests of the powerful nations of the North. If the Dutch milk imported into South Africa is cheaper than the milk produced by local farmers in the region outside Johannesburg and this therefore causes their bankruptcy, it makes much more sense to protect the South African market against European milk imports and let South African farmers produce their own milk rather than giving up their farms and then spending money on development aid for farmers in South Africa.

Fifthly, food justice and ecological concerns can no longer be played against each other. In the age of climate change, it is obvious that the lack of action against global warming by the main polluters of the industrial nations, has the most severe consequences for those who have the least share in causing such a situation. Since the droughts caused by global warming will effect primarily the global South, and especially Africa, everything short of a massive reduction of $\mathrm{CO}_{2}$-emission levels in the North is a massive attack on food justice in the future.

Sixthly, ecological considerations have led to the massive promotion of the agrofuel option. Already then there were voices warning against the consequences for food supply. Today we must admit that these voices were right. It would have been better to listen to our human intuition that food is primarily there to be put into people's mouths rather than into motors. We have to re-shift priorities. The promotion of agrofuel must be stopped until every human being on this earth has enough to eat.

Seventhly, if we take seriously that the option for the poor is a self-critical option, then we must stop blaming 'the others'. Governments in the North must take responsibility for the history of injustice during the times of colonialism. They have to recognise their role in increasing their own wealth by using the resources of countries in the South without appropriate compensation. They must stop the use of their immense historically grown economic power exclusively for their own interests rather than for the mutual interest of all. Governments and activists in the South are called to identify the points where failures of good governance contributed to the lack of food production, rather than to attribute all evil to the history of colonialism. They should put new efforts into building up a civil society and a civil administration that is oriented to the common good rather than being a place for personal enrichment. 


\section{Justice and public theology - the role of the Church}

What do these challenges mean for the church? The church must be a public church inspired by public theology. In light of public theology the option for the poor leads to advocacy and advice. In contrast to most forms of the utopian model it does not bind the poor to a specific political option but sees this option as the basis for a political discourse leading to political strategies also applicable for those in power. However, to be clear: the church is not neutral in the political debate but sees itself as an advocate of the poor. The church explicitly includes the value dimension in its contribution to the public debate. This means that contributions range from public statements - when there is a chance to be heard - to demonstrations and even limited acts of civil disobedience when this is the only way to point out grave injustices. However, other than in the utopian model, these acts are not primarily understood as acts of confessional witness and resistance against 'the system' (whatever this system exactly is or may be) but are an integral part of a strategy of public communication in a democratic society to promote political steps to overcome poverty.

In its public statements - this is another important point - the public theology model is bilingual (Harasta 2009:184-199). On the one hand, it gives account of its biblical and theological roots using biblical texts and metaphors, and on the other hand it shows why its proposals and affirmations are plausible and make sense for all people of good will, using the language of secular discourse. In this it honours the fact that faith and reason are complementary, not contradictory.

Public theology is inspired by many impulses of Latin American liberation theology, further developed in various other liberation theologies. However, since it has grown out of a democratic society it works with the presupposition of a public realm, which gives room for the constant effort to raise consciousness for political options in favour of the poor. Other than in a military dictatorships from which liberation theology originally developed, public theology tries to develop political options not only as a means of opposition but also as advice to those who hold political power. Presidents in South Africa as much as in Brazil, in their efforts to overcome poverty, need churches moving from liberation theology to public theology. That is why I say: 'Public theology is liberation theology for a democratic society' (Vellem 2007:128-237). A public church must translate the impulses of liberation theology into plausible contributions to the public debate in democratic and pluralistic societies.

\section{Conclusion}

\section{Public involvement for food justice}

Let me conclude with a thought by Dietrich Bonhoeffer emphasising the public responsibility of every Christian. Often private morality is still given a preference when we look at our moral responsibility. Dietrich Bonhoeffer's life and theology was a continuous protest against such priorities. In a passage in his Ethics, which is also part of his famous treatise After Ten Years in the Letter and Papers from Prison, he writes:

Some who seek to escape from taking a stand publicly find a place of refuge in a private virtuousness. Such persons do not steal. They do not commit murder. They do not commit adultery. Within the limits of their powers they do good. But in their voluntary renunciation of publicity they know how to remain punctiliously within the permitted bounds which preserve them from involvement in conflict. They must be blind and deaf to the wrongs which surround them. It is only at the price of an act of self-deception that they can safeguard their private blamelessness against contamination through responsible action in the world. (Bonhoeffer 1992:66, author's translation)

There couldn't be any more urgent a plea for giving the problems of food justice a central place in our reflections on the good Christian life. Both because of the seemingly remote character of these problems and their nonresolvability is there an especially vivid temptation to keep them out of our lives and pursue private virtuousness. Bonhoeffer encourages us to direct a significant part of our available time to what is happening around us nationally and internationally. He encourages us to read the Bible and the newspapers, as Karl Barth has put it. Then only will questions of international food justice become part of our lives, even if we, ourselves, have plenty to eat.

A church which honestly prays: 'give us today our daily bread' must become a public church, engaged in struggling for a world in which God's gift of daily bread reaches every human being on this earth. This is our calling and this is our promise.

\section{Acknowledgements Competing interests}

The author declares that he has no financial or personal relationship(s) which may have inappropriately influenced him in writing this paper.

\section{References}

Bedford-Strohm, H., 1993, Vorrang für die Armen. Auf dem Weg zu einer theologischen Theorie der Gerechtigkeit, Gütersloher Verlagshaus, Gütersloh.

Bedford-Strohm, H., 2007, 'Nurturing Reason. The Public Role of Religion in the Liberal State', NGTT 48, 25-41.

Boff, C. \& Pixley, J., 1987, Die Option für die Armen, Patmos, Düsseldorf.

Bonhoeffer, D., 1992, Ethik, I. Tödt et al. (Hrsg.), Chr. Kaiser, München.

Duchrow, U., 1995, Alternatives to Global Capitalism. Drawn from Biblical History, Designed for Political Action, International Books, Utrecht.

Harasta, E., 2009, 'Karl Barth, a Public Theologian? The One Word and Theological "Bilinguality", International Journal of Public Theology 3(2), 184-199. http:// dx.doi.org/10.1163/156973209X415990

Luther, M., 1962, 'Trade and usury (1524)', Luther's Works, vol. 45: The Christian in Society II, W. Brandt (ed.), Muhlenberg Press, Philadelphia. Nürnberger, K., 2005, Luther's message for us today. A South African Perspective, Cluster Publications, Luther's message
Pietermaritzburg.

Rawls, J., 1971, A Theory of Justice, Cambridge University Press, Cambridge.

Segbers, F., 2002, Die Hausordnung der Tora. Biblische Impulse für eine theologische Wirtschaftsethik, Wissenschaftliche Buchgesellschaft, Darmstadt.

United Nations, 2010, The Millennium Development Goals Report 2010, viewed n.d., from http://www.un.org/millenniumgoals/pdf/MDG\%20Report\%202010\%20 En\%20r15\%20-low\%20res\%2020100615\%20-.pdf\#page=13

Vellem, V.S., 2007, 'The Symbol of Liberation in South African Public Life. A Black Theological perspective', PhD thesis, Department of Dogmatics and Christian Ethics, University of Pretoria. 